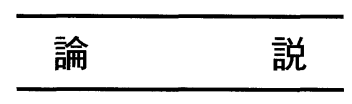

副鼻腔炎に対するマクロライド療法の現状

大山 勝1) $・$ 上野 員義 ${ }^{2)} \cdot$ 松根 彰志 ${ }^{3)}$

花牟礼 豊4) ・鶴丸 浩士5)

\title{
Current Status on Macrolide Therapy in Chronic Sinusitis
}

\author{
Masaru Ohyama \\ (Ohshima Medical Association Hospital) \\ Kazuyoshi Ueno and Shoji Matsune \\ (Kagoshima University) \\ Yutaka Hanamure \\ (Kagoshima City Hospital) \\ Hiroshi Tsurumaru \\ (Imakiire Hospital)
}

The clinical efficacy of low-dose and long-term Macrolide therapy such as Erythromycin (EM), Roxithromycin (RXM), and Clarithromycin (CAM) in the treatment of chronic sinusitis was analysed retrospectively over the past 8 year period as represented in the Japanese literature.

Patients treated with these macrolides demonstrated an improvement in both quality and quantity of nasal discharge. Notably, patients who received RXM demonstrated better improvement of rhinorrhea than patients treated with EM or CAM. CAM was judged to be useful in the treatment of sinusitis in children, showing greater improvement and a faster recovery period as compared to improvements in adults.

The Excellent synergism of both Ciprofloxacin and RXM or CAM on P. aeruginosa in biofilms was discussed from the standpoint of their pharomacological action in biofilms. Combined therapy using sinus irrigation or a YAMIK catheter for treatment of sinus secretion and macrolide administration was presented as a new therapeutic modality for treatment of chronic sinusitis.

Drug interactions with EM, CAM, but not with RXM, and antiallergic agents such as Terfenadine and Astemisole were demonstrated as one of the adverse effects occurring in clinical practice.

Key words : chronic sinusitis, macrolide, clinical efficacy, drug interaction, biofilm

はじめに

14員環マクロライド薬がびまん性汎細気管支炎 (DPB) ならびにそれに合併した副鼻腔炎に有用なことが報告さ
れて 8 年有余が経過した1)2)。この間，慢性副鼻腔炎の 治療法は, ニューマクロライドと呼ばれる抗生物質の登 場とマクロライド薬の薬理新作用の解明もあって, 大き
1）大島郡医師会病院

3）鹿児島大学耳鼻咽喉科学教室

5）今給黎病院耳鼻咽喉科
2）鹿児島大学付属難治性ウイルス疾患研究センター

4）鹿児島市立病院耳鼻咽喉科 


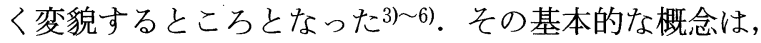
マクロライド薬を抗菌作用といらよりは生物学的, 免疫 学的調整作用飞視点を置いて少量長期間使用することに ある、いわゆる“マクロライド薬による少量長期投与療 法”と呼ばれるもので，本療法は慢性副鼻腔炎の有力な 保存療法の一つとして診療の現場で皃涪定着しつつある 感がある。そこで，本邦に和けるこれまでの慢性副鼻腔 炎に対するマクロライド療法の実態を把握し, 保存療法 の現況と意義, さらには治療全般での本療法の位置付け などについて若干の考察を加えて解説する.

\section{慢性副鼻腔炎の病態と治療の視点}

副鼻腔炎の発症とくに慢性化の機序には, 生体側の全 身的, 局所的要因と侵入異物による洞粘膜炎症の悪循環 機構を挙げることができる. 生体側の要因としては, 解 剖学的な素因, 栄養や環境などの要因に加えて, 微生物 感染や抗原の洞内侵入が基本となる。これらの要因によ って, 一旦, 洞粘膜に炎症が成立すると腺分泌充進, 粘 液繊毛輸送能の低下, 洞貯留液による物理的障害や各種 生理活性物質などの影響を受けて, 粘膜病態は一層増幅 されて, 洞病変の悪循環が進行する。また, 粘膜障害, とりわけ緘毛上皮の障害は, 洞自然孔の閉塞に発展し, 洞換気不全に陥ることになる(図 1)。したがって, 副鼻 腔炎の治療で重要なことは，この悪循環をどこで断ち切 るかであり, 最終的には洞自然孔の閉塞改善と粘液繊毛
輸送能の正常化が最も大切となる。また，一部疾患では HLA の BW547) 素因が注目されているが，上述の病態 を惹起することでは, 感染をめぐる問題が重視される. ウイルス感染(6)899) や細菌の関係する内毒素, 菌体成分, 免疫複合体さらにはバイオフィルム10)などの関与が粘 膜病変形成や治療上大きな問題となっている．14員環マ クロライド薬は, このような病因やそれらによる洞粘膜 病態に卓効を示すことがわかっている.

一方, 慢性副鼻腔炎の臨床病変は, (1)感染・炎症性, (2)アレルギー性, (3)アスピリン喘息性(仮称)そして(4)無 症候性に分類できる。これらの中で, 感染・炎症性のも のは, 病型的には分泌物貯留型やポリープ型が多く, 治 療経過によって線維型をとることが知られている。また， アレルギー性のものは多くがポリープ型, 浮腫・囊胞型 の病型をとり, アスピリン喘息性ではポリープ型, そし て無症候性のものでは囊胞型と線維型が多くみられる. マクロライド療法の良い適応となるのは, 分泌物貯留型 で最も効果的であり,ポリープ型の一部も有効とする報 告がある.

\section{マクロライド薬の作用機序}

マクロライド薬には，基本骨格が14員環のもの，16員 環のもの，そして最近，15員環のものなどがある。これ らのなかで, 慢性呼吸器疾患飞対して少量長期投与で効 果がみられるのは，14員環のマクロライド薬である，古

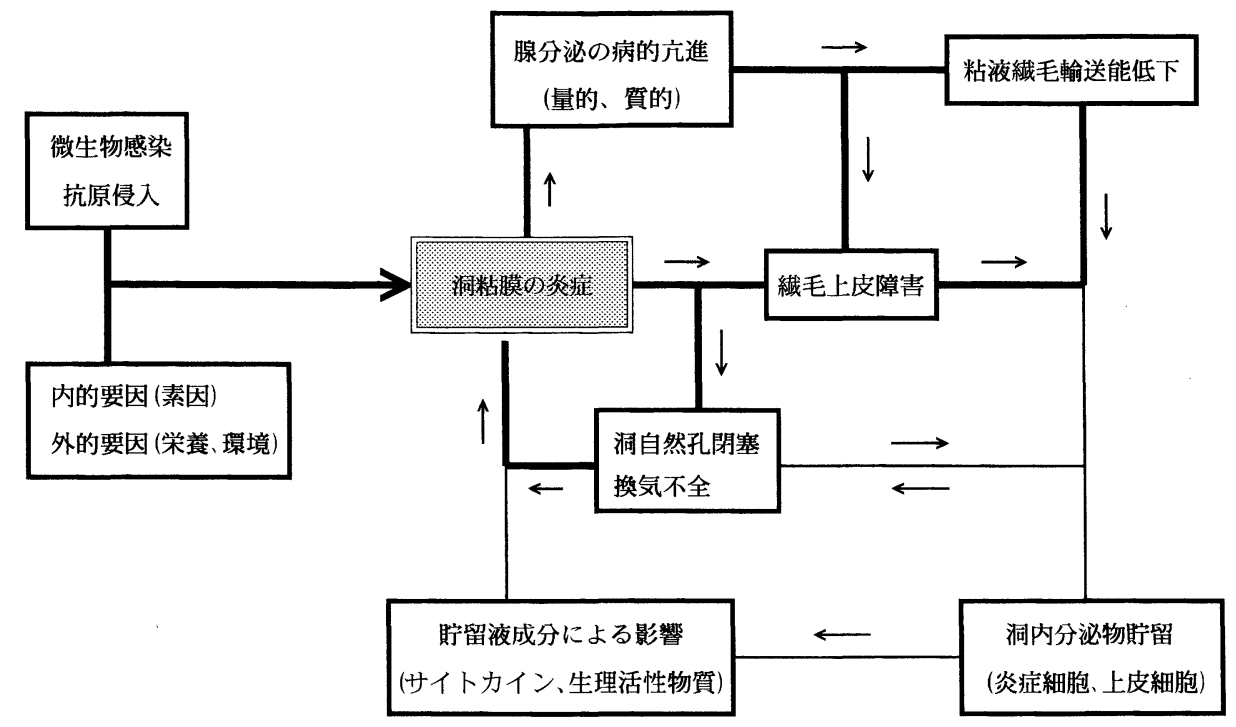

図 1 慢性副鼻腔炎の発症之病態の悪循環機序 
くは，エリスロマイシン $(\mathrm{EM})$ に始まるが，最近は，酸 飞安定で吸収が良く，かつ血中濃度や組織移行性の高い ニューマクロライドと呼ばれるものが実地臨床で用いら れている.すなわち，EM飞加觉てロキシスロマイシン (RXM)， クラリスロマイシン (CAM) が広く鼻科臨床で 使用され，一定の効果が明らかとなっている. 元来，こ れらの薬物は，抗菌薬として登場しているが，その他の 作用として消化管の運動を高めるモチリン様作用と免疫 あるいは生体防御能を高める免疫調節能としての作用な どが知られている(図 2)。したがって，これらマクロラ イド薬を少量で長期に用いることでの効果は，抗菌作用 もさることながら免疫調節能としての作用によるものと 考兄られている. 事実，これらの新作用に関寸る研究成 果は，過去10年間に蓄積されつつある。なかでも注目さ れる主な作用は，(1)気道の病的分泌を調整する作用であ る. 気道上皮細胞に動いてて1112)，イオンチャネルに関与 して水の分泌を抑制131414) したり，腺細胞に働いてムチ ンの生成 ${ }^{15)}$ ，とくに過剩なフコースを調整して，シアル 酸とフコースあるいはマンノースとの量的バランスを計 り16)，異常になった組成を正常化する6)ことが明らかに されている.

(2)炎症巣に和ける上皮細胞や浸潤細胞からのサイトカ インや接着分子の生成を調節する作用がある。なかでも， マクロライドにみられる好中球の浸潤，集積に対する抑 制効果6)1718) は，ヶモカイン， IL-8 の生成抑制作用，血 管内皮細胞への接着分子の発現抑制や IL- $1 \beta, T N F \alpha$ な ぞ炎症性サイトカインの生成抑制19) 23) によることが明

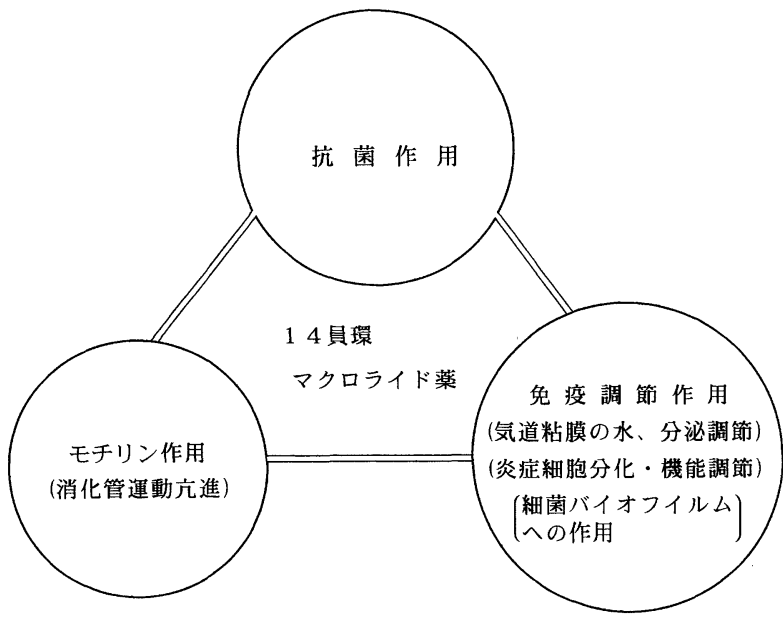

図 214 員環マクロライド薬の薬理作用
らかにされている。このよらな作用により，好中球を始 め炎症細胞の長期にわたる病巣への集積を防止し，その 結果，好中球などからの生理活性物質やスーパーオキサ イドの産生を抑制して炎症の慢性化を断ち切ることが考 えられる. マクロライド薬が気道の慢性病態に対して, 炎症の遷延化，難治化，そしてこれら悪循環の制止に貢 献するといら根拠ともなっている。 また，マクロライド 薬は, 炎症巣で密接に関与するマクロファージやリンパ 球21)などに対しても分化や機能面で幾つかの調整作用 を示すことが知られている.

一方，(3)本薬の細菌に対する作用では，特筆すべきも のにバイオフィルム産生抑制や分解作用を挙げることが できる10)。例咒ば，緑膿菌は通常，非ムコイド型，すな わちアルギネートを分泌しないタイプをとっているが， その場合，生育環境の悪い状態になるとアルギン酸を含 んだ複合糖質，ムコイドが生成されて菌自体はムコイド 型に変わることがわかっている．その際，多数の菌体は 寄り添ってこれら多量の糖衣(バイオフィルム) に覆われ て生息する状態をとる。そして，環境が良くなると糖衣 を剥がして菌の増殖を执こし，生体組織の病態を増悪す るのである。したがって，細菌の抵抗性の一つには，こ のアルギネートの産生すなわち細菌バイオフィルム形成 が関与することがわかったのである。、クロライド薬は， 緑膿菌に対して単独では全く抗菌作用を示さず，また ニューキノロン薬もバイオフィルムを持った緑膿菌には あまり効果がみられない。しかし、ニューキノロン薬に 14員環マクロライド薬を併用すると両者それぞれ単独で は効果のみられなかったバイオフィルム緑膿菌に対して 著明な殺菌作用を示すことが実証されている．事実，マ クロライド薬が in vitro で緑膿菌バイオフィルムを溶解 すると共に，菌体の変化や増殖を抑制する像を超微形態 的に把觉ている2425). DPBなどでの緑膿菌感染に対して, マクロライドが卓効を示し，肺病変の改善に貢献する仕 組みが明らかになったのである。このよらに，マクロラ イドは生体側の要因と共に細菌側の要因の両者 ${ }^{26) 27)}$ か ら, 慢性病態改善に直接, 間接的に貢献していることが わかる。

\section{慢性副鼻腔炎に対するマクロライド療法の成績比較}

慢性副鼻腔炎に対する14員環マクロライド療法は, 1990年以来 EM でスタートしたものが122)，1993年頃を 境に RXM，CAM などニューマクロライドの使用例が 
著しく多くなっている28) 31)。ニューマクロライド薬に 関わる研究は，臨床成績に止まらず基礎分野でも多くな っている(表 1).

これらの論文を薬物別に収集すると, 当然のことであ るが，当初は EM の論文が多かったが最近は， RXM の

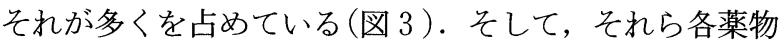
別の平均有効率は， RXM (23編)のそれで $78 \%, \mathrm{CAM}$ (16編)で $71 \%$ ，EM (15編)のそれが63\%となり，RXM が最も高い有効率を示している.

マクロライドの臨床効果については, 自覚症状では鼻 漏, 後鼻漏などの分泌物の改善が最も多く観察されるが,

表 1 慢性副鼻腔炎に対するマクロライド療法

\begin{tabular}{|c|c|c|c|c|c|c|}
\hline & \multirow{2}{*}{ 論文数 } & 種 & 類 & \multicolumn{3}{|c|}{ 薬剤の種類 } \\
\hline & & 基 礎 & 臨 床 & RXM & CAM & EM \\
\hline 1990年 & 3 & & 3 & & & 3 \\
\hline 1991年 & 6 & & 6 & & & 6 \\
\hline 1992年 & 8 & 2 & 8 & 1 & & 7 \\
\hline 1993年 & 12 & 1 & 11 & 6 & 5 & 1 \\
\hline 1994年 & 7 & 2 & 7 & 4 & & 4 \\
\hline 1995年 & 25 & 8 & 20 & 18 & 7 & 4 \\
\hline 1996年 & 37 & 12 & 28 & 19 & 15 & 10 \\
\hline 1997年 & 21 & 8 & 13 & 12 & 7 & 4 \\
\hline
\end{tabular}

RXM, CAM, EM の3 薬間では大差がみられない(図 4 ）. 一方, 他覚所見について解析すると, 分泌物の量, 性状の変化とくに後鼻漏の改善に著しい効果が認められ る.なかでも, RXM の改善率は他の 2 つの薬物に比し て著しく高いことが判明したことは特記すべきであろう (図 5 ).

さて，抗菌薬治療で常に問題になるのは，長期あるい は頻繁に使用することによる有效性の変化と菌の薬物耐 性化の問題がある.

図 6 は14員環マクロライド薬の慢性副鼻腔炎に対する 治療成績で， 3 薬の平均有効率を年次別にみたものであ る (図 6 ). 有効率は 3 つの薬物の平均值としてみる限り, $60 \sim 80 \%$ 以内で, 過去 8 年間のマクロライド薬の治療成 績に大きな変化がみられることはない，日常臨床で，慢 性副鼻腔炎に対する抗生物質療法中，マクロライド薬の 使用件数が多い(図 7 ) 上に, メチシリン耐性ブドウ球菌 に加兄て，ペニシリン低感受性肺炎球菌やペニシリン耐 性肺炎球菌など肺炎球菌の耐性問題が注目されているが, 現在のところ，マクロライド薬の少量長期療法による明 らかな影響は注とんどみられないよらである。ただ，市 中感染症の中でのペニシリン耐性肺炎球菌の問題が地球 規模で注目されているので注意深い観察が大切であろう.

小児副鼻腔炎のマクロライド療法

小児副鼻腔炎の治療では, 鼻副鼻腔の病変と共にアデ

有効率 $(\%)$

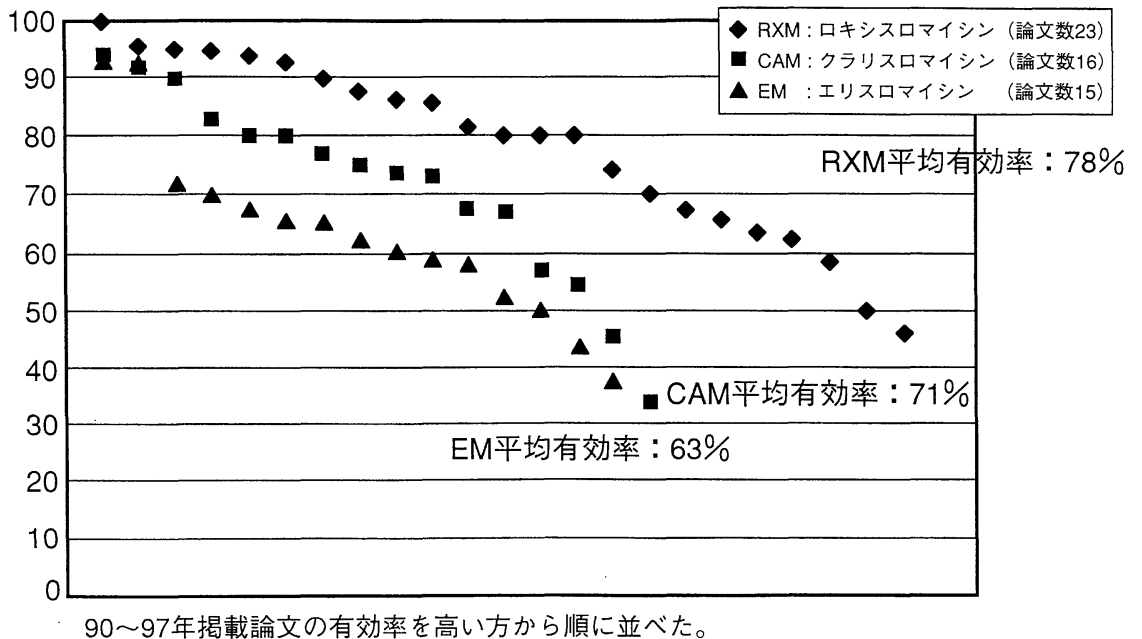

図 3 慢性副鼻腔炎に対するマクロライドの論文別有効率比較

（90〜97年掲載論文より） 


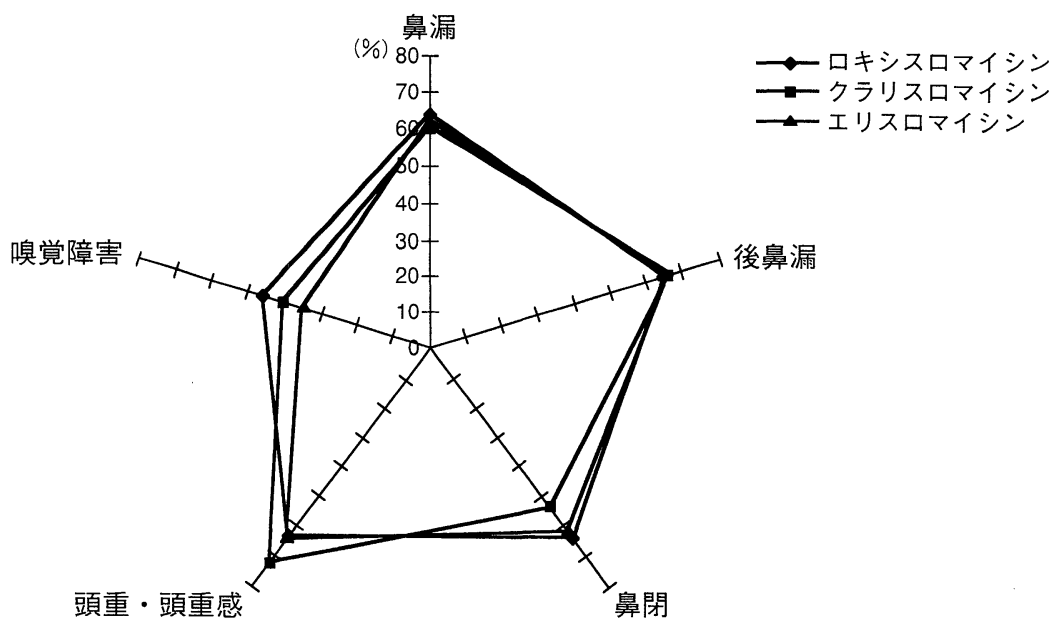

図 $495 \sim 97$ 年掲載論文の平均改善率 （自覚症状）

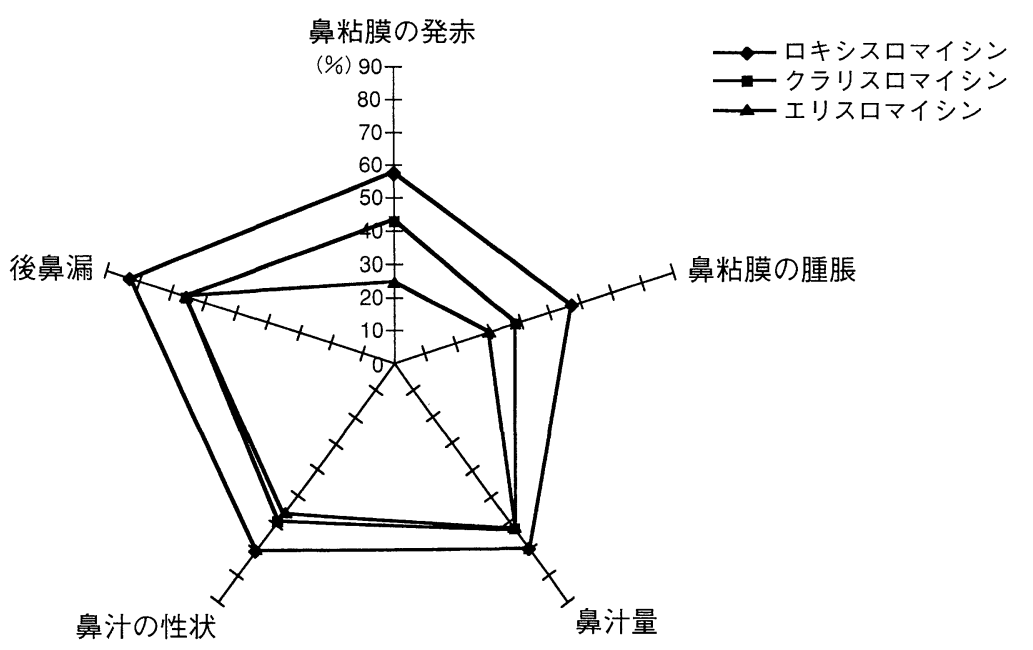

図 $595 \sim 97$ 年掲載論文の平均改善率 (他覚所見)

ノイド増殖症やアレルギー性病変の関与32) が問題とな る. 幼小児の場合, 鼻をかんで分泌物を除去する行為が 十分満足にでさない例が多いので, 鼻腔や洞洗浄さらに は，YAMIK 法などによる洞分泌物の積極的な除去が大 切である33)34)。また小児では，マクロライド薬の中，適 応となっているのは，EM と CAM であるため使用薬に 制限がある35)36). 図 8,9 は大学, 関連病院, 開業医と の共同臨床研究での CAM の治療成績を示している31). 小児に括いては，自覚症状で鼻のかみやすさが著明に改
善するのに加えて，他覚所見でもX線像の改善が成人に 比して著明に高い成績が得られている.また治療経過(図 10)をみると，成人では 4 週で一つの改善のピークを有 しながら 8 週まで徐々に改善率が上がり，その後プラ トーに達するのに対して，小児のそれは 6 週まで改善率 が上がり，その後はプラトーになることがわかった．換 言すれば，成人の慢性副鼻腔炎に対するマクロライド療 法は，概ね 4 週で一応の効果の判定は可能であるが 8 週 まではさらに症状の改善が期待でさること, それに対し 


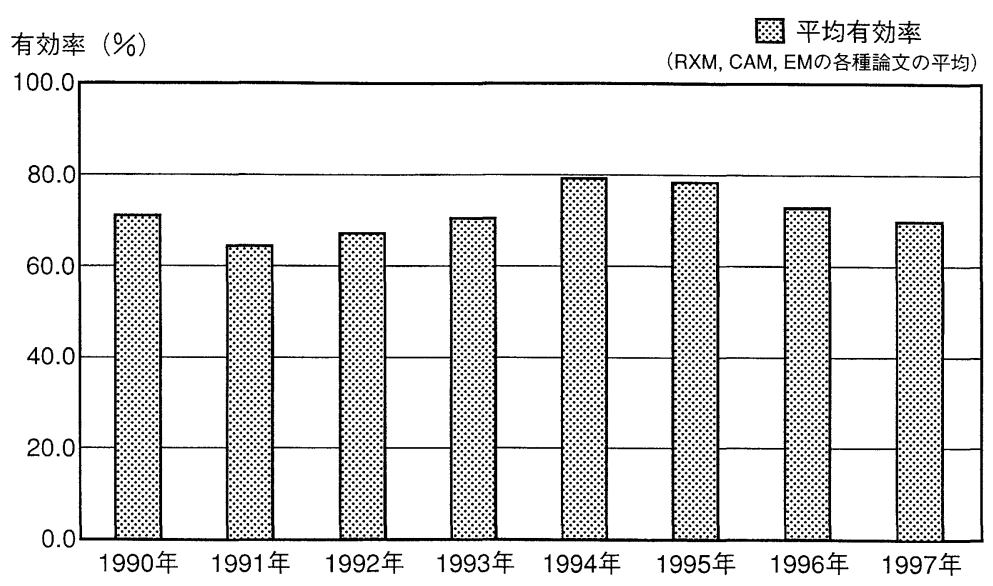

図 6 慢性副鼻腔炎に対する14員環マクロライドの有効性年次推移

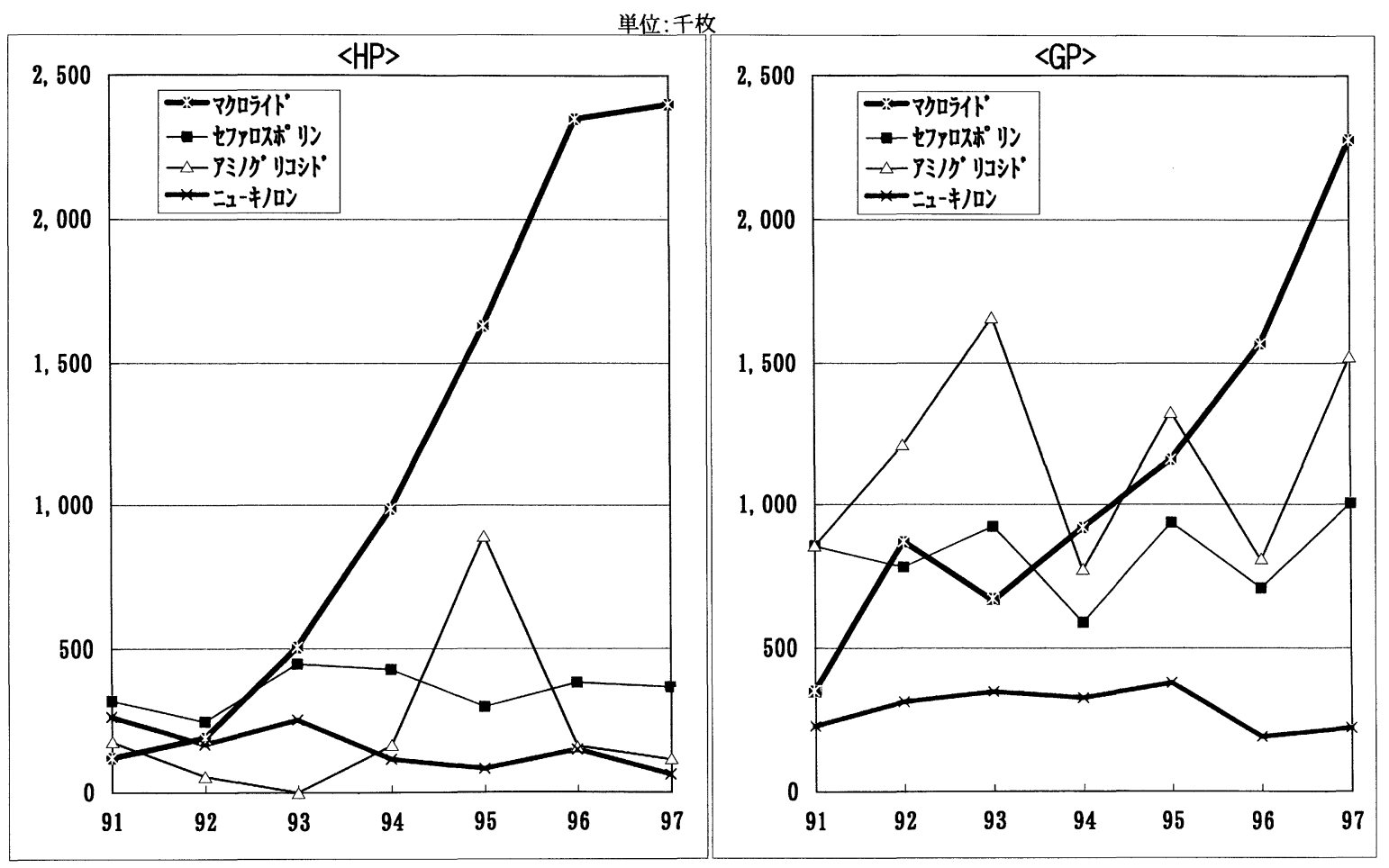

図 7 慢性副鼻腔炎に対する抗生剂の処方箋枚数の推移

て小児のそれは，成人の改善率飞遅れて 6 週で一応の ピークに達し，それ以降のさらなる改善はあまり望めな いことを暗に示唆している.

\section{マクロライド療法の効果を高める治療}

前述のごとく，マクロライド薬には気道の病的分泌を
調整したり，病巣の炎症細胞の機能を調節する作用があ るので, 副鼻腔の分泌物貯留液を排除したり ${ }^{33334)}$, 排泄 を助けることは37)，それ自体が薬物効果を高めることに 相通ずることになる。したがって, 副鼻腔炎の治療にあ たっては，漫然と薬物療法に頼るのでなく，洞分泌物の 排泄助長あるいは積極的な排除努めるべきである。臨 


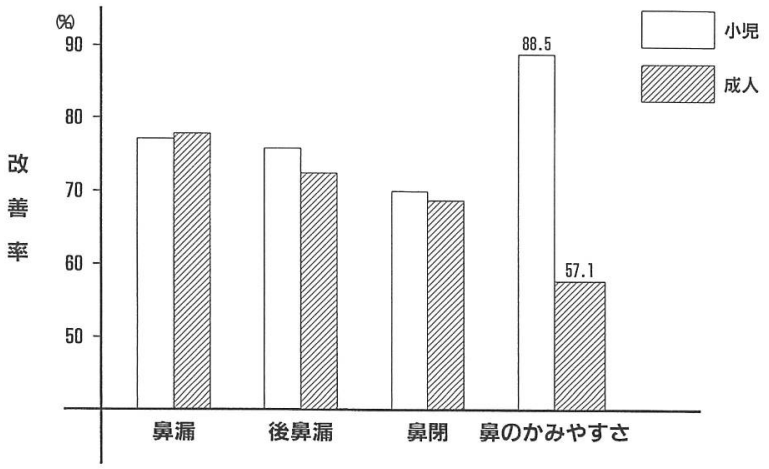

図 8 自覚症状の改善率比較成績

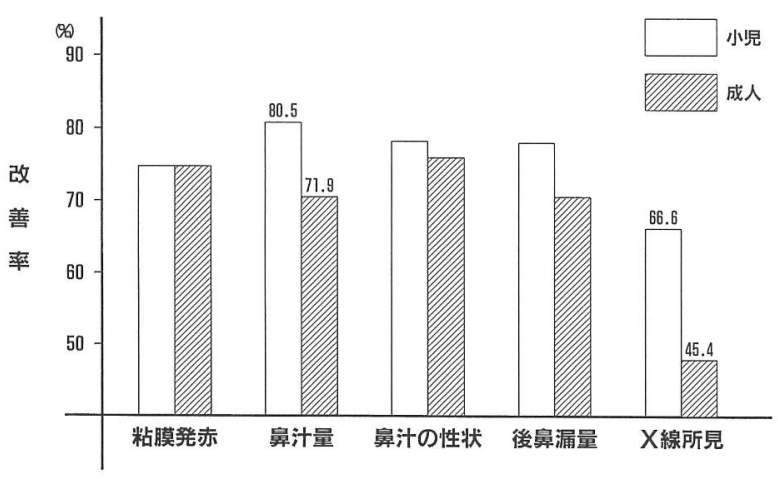

図 9 他覚所見の改善率比較成績

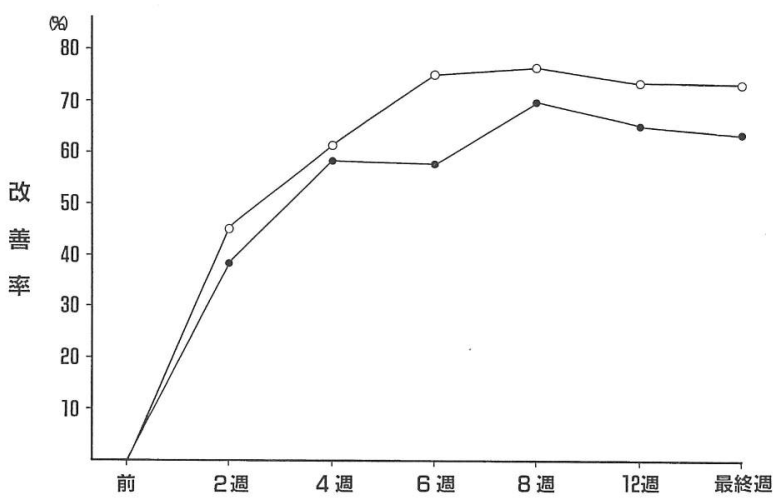

図10 成人，小児副鼻腔炎治療の週別改善率比較成績

床の現場では(1)鼻処置などを丁寧に行い洞自然孔の開大 をはかる，(2)洞貯留液の積極的な排除，(3)中鼻道病的粘 膜，ポリープなどの処置等を行い，これら非観血的療法 にもかかわらず病変の改善がみられない例には, 経鼻的

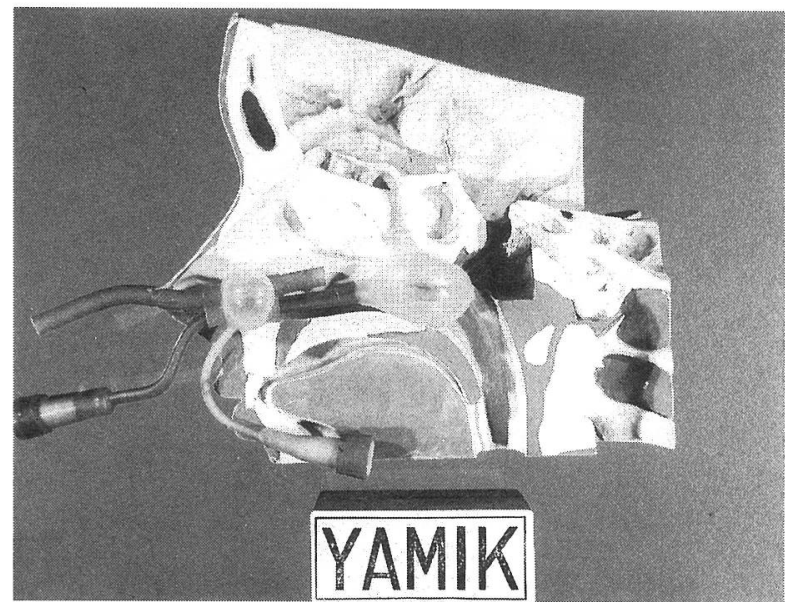

図11 鼻副鼻腔モデルでの YAMIK カテーテル装置状態 (1)前鼻孔括よび後鼻孔側をバルーンで閉塞する.

(2)治療用チャネルを介して注射器で陰陽圧 (ペンピング) を加亲ながら，鼻腔を陰圧にして，洞分泌物を誘導， 排除する。

内視鏡副鼻腔手術 (ESS，FESS) や蓋付骨并形成副鼻腔 手術などを行い，術後再びマクロライド療法を行らと良 ( $(38)$.

最近，われわれはマクロライドの少量長期療法の効果 を高める方法の一つとして, YAMIK 副鼻腔治療用力 テーテル(図11)を活用して予期以上の効果が得られてい る39)。矢れには，副鼻腔炎患者で分泌物貯留型に対して は, 本 YAMIK 療法で洞貯留液を週 1 回排除しながら マクロライド薬の少量(常用量の $1 / 2$ ) 投与を併用するこ とで優れた効果と症状の改善期間を著しく短縮できるこ とを経験している(図12).

また鼻茸症例では，レーザー鼻茸切除後（1 週〜 10 日 後)に YAMIK 療法とマクロライド療法を行い比較的良 好な成績が得られている(表 2 )。同様にアレルギー性鼻 茸に詨してもレーザー手術, YAMIK 療法乞して抗アレ ルギー薬投与による併用療法を行っているが，約半数に 鼻茸再発がみら机炎症性鼻茸の治療成績に比して劣るも のであった。

\section{マクロライド薬の薬物相互作用}

マクロライド薬を使用する場合，抗アレルギー薬，抗 真菌薬，気管支拡散薬などの一部との併用には薬物相互 作用の点から十分注意しなければならない40041)。耳鼻咽 喉科の対象症例では，気道アレルギー，アトピー疾患， 

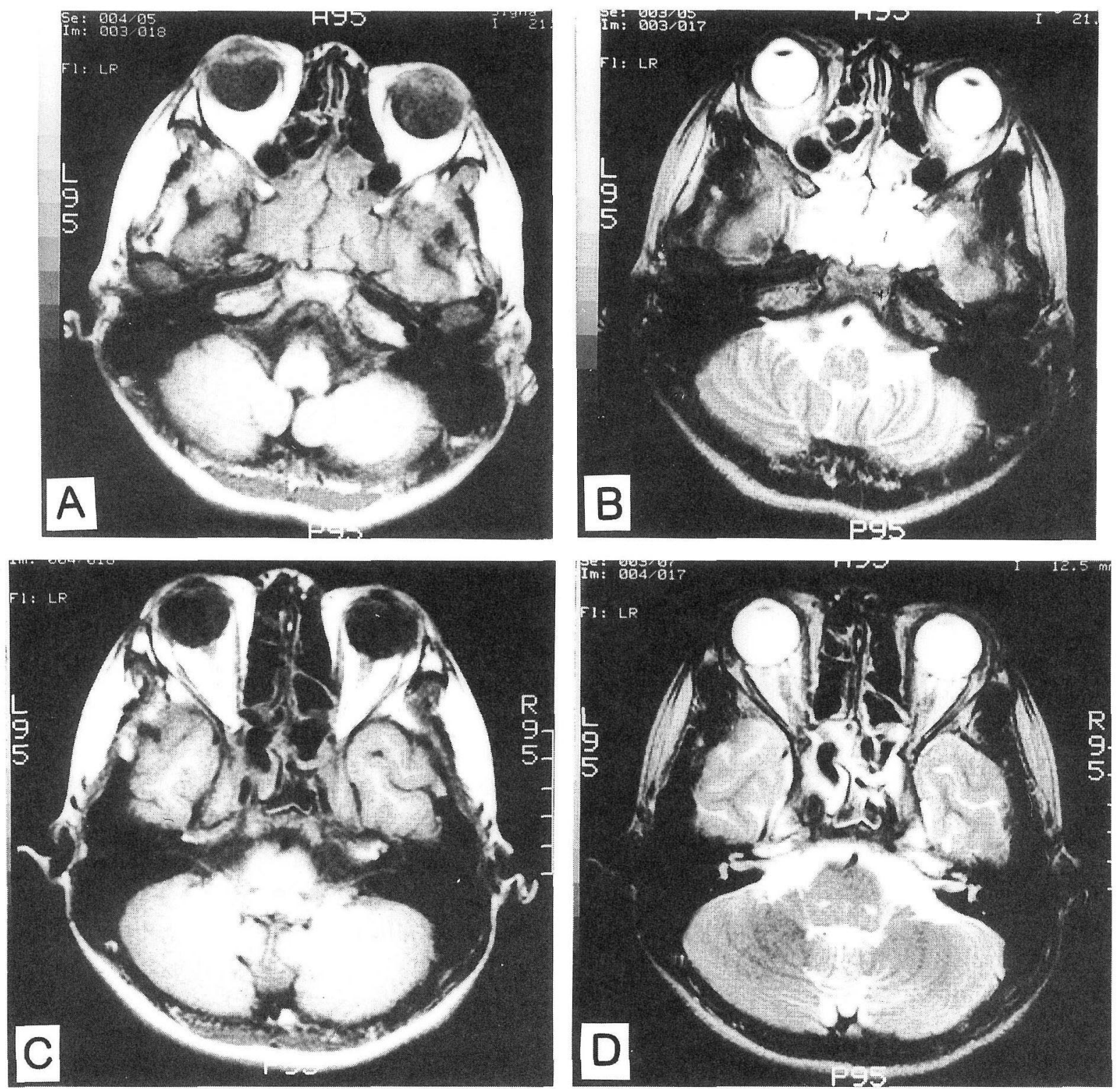

図12 急性篩骨洞蝶形骨洞炎症例の MR 像 16歳, 男性(YAMIK 療法例)

上段治療前：A：T1 像， B : T2 像

下段治療後：C：T1 像, D : T2 像

真菌症で治療中の患者や循環器疾患, さらには高龄者を 含めて合併症を持った患者がみられるので，本薬の投与 に際しては十分な問診と慎重さが要求される.

表 3 は14員環マクロライド薬の主な薬物相互作用を示 したものである．EM やCAM には耳鼻咽喉科臨床で使 われる薬物や循環器用薬との間飞禁忌ないしは慎重投与 すべきものがあるが，RXM との間では注意事項となっ
ている。したがって RXM は上述の 2 薬に比べて薬物 相互作用での影響は少ないのであるが，マクロライド薬 である以上，併用療法には十分慎重を期すべきは論をま たない。

ここで，マクロライド薬の肝代謝過程に特忷る他薬物 との相互作用の仕組みに簡単にられることにする.

マクロライド薬を含めて多くの薬物は肝臓で代謝され 
表 2 レーザー鼻茸切除術と YAMIK 療法に併用した薬 物別, 病態別治療成績比較

\begin{tabular}{|c|c|c|c|c|c|c|}
\hline \multirow[b]{3}{*}{ 病 態 } & \multicolumn{3}{|c|}{ 併 } & \multicolumn{3}{|c|}{ 薬 } \\
\hline & \multicolumn{3}{|c|}{$\begin{array}{l}\text { 抗アレルギー薬 } \\
\text { (含ステロイド) }\end{array}$} & \multicolumn{3}{|c|}{ マクロライド薬 } \\
\hline & 改善 & 不変 & 再発 & 改善 & 不変 & 再発 \\
\hline $\begin{array}{c}\text { アレルギー性 } \\
(\mathrm{n}=12)\end{array}$ & 4 & 0 & 4 & 2 & 0 & 2 \\
\hline 炎 $(\mathrm{n} \stackrel{\text { 症 }}{=} 18)^{\text {性 }}$ & 3 & 1 & 1 & 10 & 1 & 2 \\
\hline
\end{tabular}

るが，その際，肝内のミクロゾームに取り込まれてチト クロームP450 の CYP3A4 によって代謝される ${ }^{42)}$. この CYP3A4 によって代謝される主な薬物には，マクロラ イドなどの抗菌薬，テルフェナジン，アステミゾールな どの抗アレルギー薬を筆頭に循環器用薬, 向精神薬, 抗 潰瘍薬，免疫抑制薬などがある。また CYP3A4 の働き を阻害する薬物としては，ミコナゾール，フルコナゾー ルなどのアゾール系抗真菌薬，EM，CAM な゙のマク ロライド薬，シメチジンなど抗潰瘍薬が知られている. この CYP3A4 の代謝阻害の起こる現象は, 代謝によっ て生じた薬物の中間代謝物が，CYP3A4 の活性中心で あるへム鉄に結合し複合体を形成することで，CYP3A4 の酸素活性が失われることによって生ずる.

EM や CAM は CYP3A4 で代謝されると同時に CYP3A4を阻害する作用を有するので，前述の CYP3A4 によ り代謝される他の薬物を併用すると様々な有害事象が生 ずることになる(図13)。その点，RXM は EM や CAM
と比して，(1)肝ミクロゾームへの蓄積が少ない，(2) CYP3A4 との親和性が低い, (3)CYP3A4 の酵素誘導に 及洔す影響が少ない，(4)CYP3A4 との複合体形成が低 いことが明らかになっている．RXM がマクロライド薬 のなかで，問題の薬物相互作用が少ない理由となってい る、しかしながら，CYPを含めた肝の薬物代謝に関係 する酵素類は，高齢者では生成機能が低下することがあ りまた疾病によってはこれら酵素が減少していること もあるので, 薬物併用療法にあたっては年齢や全身状態 などを勘案して慎重に対処することが大切である.

\section{マクロライド薬の副作用}

マクロライド薬は前述のように肝臓で代謝されるので, 肝疾患や肝機能への影響の問題が注目されている。 しか し EM の長期 ( $3 \sim 6$ 年以上) 投与 20 例では43)，これら に関する副作用は報告されていないまた 12 週，6力月 の CAM 投与でも副作用は皆無である. RXM の投与例, 6700 余名の調查資料 $(2 \sim 8$ 週以上)では $0.9 \%$ ときわめ て少ない。

このようと現時点での EM，CAM，RXM などマクロ ライド薬の臨床使用例に护ける副作用は軽微であるとい 壳る31144)

\section{副鼻腔炎に対するマクロライド療法の指針}

1 ）適応となる副鼻腔炎の病型

分泌過㮃，炎症型の慢性副鼻腔炎拉よび手術後の慢性 副鼻腔炎.

表 3 14員環マクロライドの主な薬物相互作用

\begin{tabular}{|c|c|c|c|c|}
\hline & 併 用 薬 & ロキシスロマイシン & クラリスロマイシン & エリスロマイシン \\
\hline \multirow{2}{*}{$\begin{array}{l}\text { 耳 } \\
\text { 番 } \\
\text { 秋 } \\
\text { 使 } \\
\text { 角 }\end{array}$} & $\begin{array}{l}\text { 抗アレルギー剂 } \\
\text { テルフェナジン } \\
\text { アステミゾール } \\
\text { ェバスチン }\end{array}$ & $\begin{array}{l}- \\
-\end{array}$ & $\begin{array}{c}\text { 禁 忌 } \\
? \\
?\end{array}$ & $\begin{array}{c}\text { 禁 忌 } \\
\text { 禁 忌 } \\
\text { 減量するなど慎重に投与 }\end{array}$ \\
\hline & $\begin{array}{l}\text { 気管支拡張剤 } \\
\text { テオフィリン }\end{array}$ & 注 意 & 異常認めれば直ちに両㶡中止 & 減量するなど慎重に投与 \\
\hline 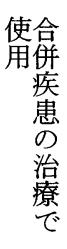 & $\begin{array}{l}\text { 循環器官用剤 } \\
\text { シソピラミド } \\
\text { フェロジピン } \\
\text { ワルファリン } \\
\text { ジゴキシン } \\
\text { エルゴタミン含有製剤 }\end{array}$ & $\begin{array}{c}\text { - } \\
\text { 注 意 } \\
\text { 注 意 }\end{array}$ & $\begin{array}{c}\text { 異常認めれば両風中止 } \\
? \\
? \\
\text { 異常認めれば減量もしくは両剤中止 } \\
?\end{array}$ & $\begin{array}{l}\text { 減量するなど慎重に投与 } \\
\text { 減量するなど慎重に投与 } \\
\text { 減量するなど慎重に投与 } \\
\text { 減量するなど慎重に投与 } \\
\text { 減量するなど慎重に投与 }\end{array}$ \\
\hline
\end{tabular}




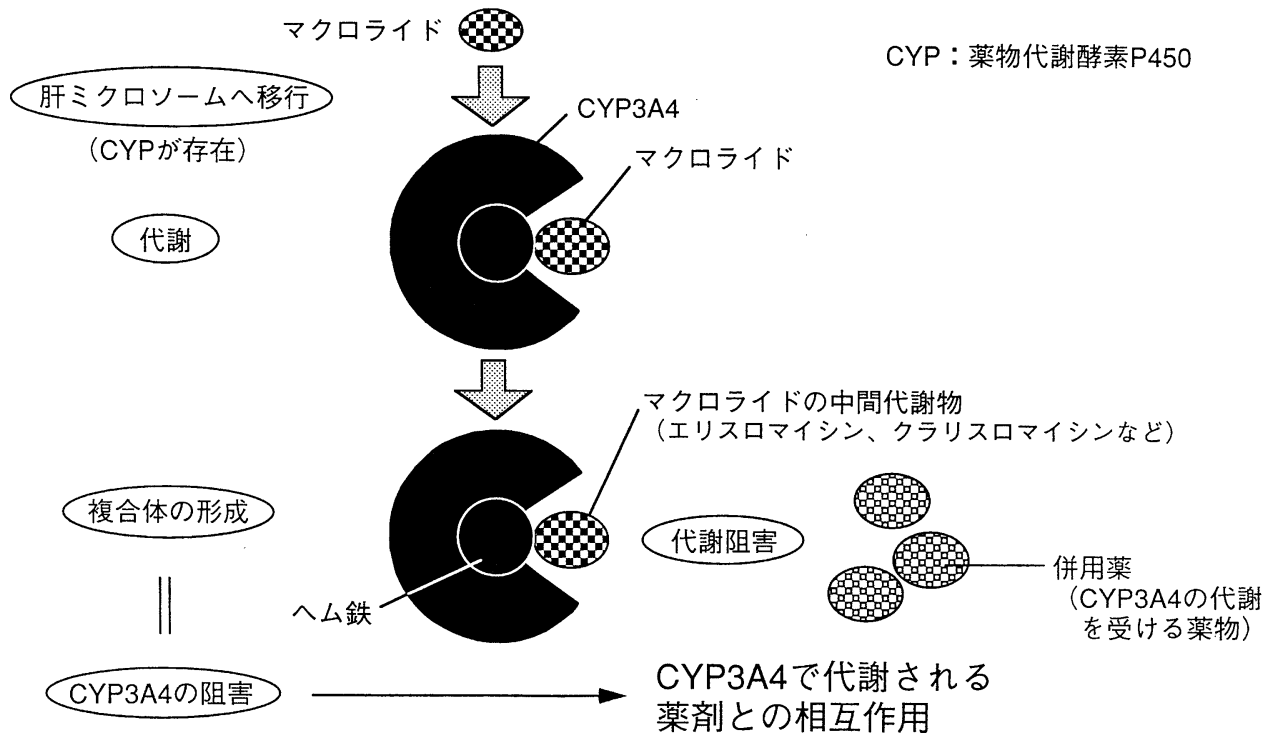

代謝によって生じたマクロライドの中間代謝物がCYP3A4の活性の中心であるへム鉄と結合し、 複合体を形成することにより、CYP3A4の酵素活性が失われ、併用薬の代謝が阻害される。

図13 マクロライド系抗生物質の相互作用のしくみ

一複合体 $(\mathrm{CYP}+$ 中間代謝物 $)$ 形成による酵素活性の阻害一

2) マクロライド薬

14 員環マクロライド薬(エリスロマイシン，ロキシス ロマイシン，クラリスロマイシン).

3 ）投与量

原則として常用量の半量.ただし次のような投与法も 選択でさる. (1)臨床症状が顕著な例では常用量で治療を 開始し，経過をみながら半量にする。（2)急性増悪時には 常用量に切り替光るか他の抗菌薬に変更する.

4 ）投与期間

原則として 6 ～ 8 週間. 十分な改善が得られない例で は投与を中止し，他の療法に切り替える.さらに改善が 予測される例では，インフォームド・コンセントを交わ して続行を決める.

5 ) 効果判定

原則として自覚症状(鼻漏, 後鼻漏)の改善を重視. $\mathrm{X}$ 線所見の改善とは必ずしも一致しないことがある. 分泌 物の減少による鼻, 咽頭乾燥感を訴えることがあるので 注意する。

6 ）併用薬での注意事項

抗アレルギー薬，気管支拡張薬などとの併用時には， 薬物相互作用に留意, 慎重を要する. とくに EM, CAM 療法では注意を要する。
7 ）マクロライド薬の効果を高める方策

洞分泌物の排除，洞換気の改善が重要. (1)鼻処置など による洞自然孔の開大に努める. (2)洞洗浄, YAMIK 療 法などを併用する。(3)粘液溶解薬，酵素薬などを併用す る。

8 ）マクロライド薬の再投与

症状再然時には再投与で効果. 前回と変らぬ効果が得 られるのが特徵である。

9 ）副作用

肝機能の推移観察．耐性菌，あるいは菌交代の問題は 等閑視すべきではない。

10）手術療法

適応とあらば，FESS あいは ESSなど低侵襲手術 （とくに鼻茸合併例）を施行し，マクロライド後療法を行 5 .

\section{まとめ}

慢性副鼻腔炎の治療理念は治癒に導くことが最重要課 題である. しかも過去の洞変形ないしは形態を破壊して 治療に導く手法でなく，鼻の重要な機能を温存，改善あ るいは正常化することで治癒に導くのが理想である。そ のためには優れた薬物療法，新しい保存療法などに加え 
て機能温存, 改善手術と丹念な鼻処置を上手に併用する ことが大切である.14員環マクロライド薬には，これら の治療理念に応えうる資格を有している。マクロライド 薬の薬理作用を知り，親しみ，上手に使うことが副鼻腔 炎の臨床で重要である。

\section{参考文献}

1 ）洲崎春海，杉田公一，工藤翔二，他：びまん性沉細気管支 炎に併発する慢性副鼻腔炎に対するェリスロマイシンの効 果. Ther Res 11: 961 963, 1990.

2 ) 菊地 茂, 洲崎春海, 青木彰彦, 他: 副鼻腔炎とェリスロ マイシン少量長期投与. 耳鼻臨床 $84 ： 41 \sim 47,1991$.

3 ）大山 勝, 古田 茂, 松永信也, 他 : 鼻副鼻腔炎の病態形 成と接着分子.耳鼻免疫アレルギー 11: 1〜 10, 1993.

4) 大山 勝, 花年礼豊, 上野員義, 他 : 副鼻腔気管支症候群 一最近の話題を中心に一. 耳鼻臨床 $88: 273 \sim 284,1995$.

5 ) Ohyama M, Furuta S, Ueno K, et al : New trend in treatment of chronic sinusitis. Asian Med J $39: 471 \sim 476$, 1996.

6 ) 大山 勝 : 鼻副鼻腔炎の病態と臨床. 分子医学から内視鏡, レーザー治療まで．金原出版，東京，1997。

7 ）洲崎春海：副鼻腔気管支症候群. JOHNS $3: 281 \sim 285$, 1987.

8 ）丸山征郎 : HTLV-I associated bronchoneumopathy (HAB) とその免疫学的側面. 臨床免疫 $21: 570 \sim 576,1989$.

9 ）園田俊郎：HTLV-I に対する宿主の免疫応答. ウイルス $42: 29 \sim 39,1992$

10）小林宏行：慢性気道感染症 一 biofilm disease としてのア プローチー．呼吸 $11: 1266 〜 1271,1991$.

11）玉置 淳, 武山 廉, 千代谷厚, 他: 気道粘膜上皮の線毛 運動に対するロキシスロマイシンの効果とその作用機序に 関する検討. 呼と循 $39: 481 \sim 485,1991$.

12) Takeyama K, Tamaoki J, Chiyotani A, et al : Effect of macrolide antibiotics on ciliary motility in rabbit airway epithelium in-vitro. J Pharm Pharmacol $45: 756 \sim 758$, 1993.

13）中田潤子, 玉置 淳, 武山 廉, 他: エンドトキシン吸入 による気道杯細胞分泌反応に対するロキシスロマイシンの 影響. 呼と循 $44:$ 1089 1092, 1996.

14) Tamaoki J, Isono K, Sakai N, et al : Erythromycin inhibits cl secretion across canine tracheal epithelial cells. Eur Respir J 5 : 234 238, 1992.

15) Goswami SK, Kivity S and Marom $Z$ : Erythromycin inhibits respiratory glycoconjugades secretion from human airway in vitro. Am Rev Respir Dis 141 : 72 78, 1990.

16）上野員義, 吉次政彦, 花牟礼豊, 他：鼻疾患と鼻汁分泌 一複合糖質の变化とケミカルメディエーター一，日鼻会誌
$32: 287 \sim 292,1994$.

17）馬場園真樹子, 松永信也, 内䓟明裕, 他 : エリスロマイシ ンの好中球活性酸素産生能へ及ぼす影響. 日耳鼻感染誌 $10: 108 \sim 112,1992$.

18）大山 勝, 松永信也, 福島 泰 : 慢性難治性気道感染症と マクロライド，4．マクロライド少量長期投与，耳鼻科領 域に扣ける検討. マクロライドの役割と今後の展望(清水 喜八郎監). 56〜 64頁，メディカスインターュン，東京， 1993.

19）門田淳一, 崎戸 修, 河野 茂, 他 : 慢性下気道感染症に 対するロキシスロマイシン長期治療 一臨床効果とサイト カインに括よぼす影響一. 感染症学雑誌 68 : 27〜33, 1994.

20) Oishi $K$, Sonoda F, Kobayashi S, et al : Role of interleukin 8 (IL-8) and an inhibitory effect of erythromycin on IL-8 release in the airways of patients with chronic airway diseases. Infect Immun 62 : 4145 4152, 1994.

21）飯野ゆき，宮澤哲夫：マクロライド療法の有効性と副鼻 腔粘膜病理. 耳展 38 補 $3: 269 \sim 273,1995$.

22) Tamaoki J, Nakata J, Tagaya E, et al : Effects of roxithromycin and erythromycin on interleukin 8 -induced neutrophil recruitment and goblet cell secretion in guinea pig tracheas. Antimicrob Agents Chemother $40: 1726 \sim$ 1728, 1996.

23）洲崎春海, 浅野和化：ロキシスロマイシン少量長期投与に よる IL- $1 \beta$ と INF- $\alpha$ の産生抑制. 耳展 40 補 $2: 164 \sim 168$, 1997.

24）大垣憲隆, 菊地直美 : 細菌 Biofilm と抗菌剂の interaction. 化学療法の領域 $8: 236 \sim 242,1992$.

25）後藤直正, 香本晃良, 西野武志: 緑膿菌バイオフィルムに 対する ciprofloxacin と Roxithromycin との併用効果. Jap J Antibiotics 48 : 595 601, 1995.

26) Ishida $\mathrm{KL}$, Ikeda $\mathrm{K}$, Tanno $\mathrm{N}$, et al : Erythromycin inhibits adhesion of pseudomonas aeiuginosa and Branhamello catarrhalis to human nasal epifhelial cells. Aner J Rhinology 9 : 53 55, 1995

27）羽柴基之, 小間晶嗣，馬場駿吉：マクロライドの非抗菌作 用一バイオフイルムに対する作用一. JOHNS 12 : 175〜 179, 1996.

28）羽柴基之, 宮本直哉, 木村利男, 他：慢性副鼻腔炎に対す るェリスロマイシン誘導体(クラリスロマイシン)の効果.

日鼻誌 $31: 269 \sim 280,1993$.

29）中川文夫, 小川晃弘, 明海国賢, 他 : 慢性副鼻腔炎に対す るロキシスロマイシン療法. 耳鼻臨床 87 : 569〜 578, 1994.

30）洲崎春海：慢性副鼻腔炎へのマクロライド療法の応用の開 始と現状. JOHNS $12: 213 \sim 220,1996$.

31）大山 勝, 古田 茂, 松根彰治, 他 : 慢性副鼻腔炎に対す るクラリスロマイシンの治療成績. 化学療法の領域 12 : 111〜119, 1996 
32）大山 勝, 大野 聖, 昇 卓夫 : 小児副鼻腔炎の治療一 薬物療法に関して一. 耳鼻臨床 $71: 1231 \sim 1234,1978$.

33）久保伸夫, 中村晶彦, 井野千代徳, 他 : YAMIK 副鼻腔炎 治療用カテーテルの検討. 耳鼻臨床 $87: 773 \sim 782,1994$.

34) 大山 勝, 久保伸夫, 中村晶彦, 他: YAMIK カテーテル 法の臨床的検討. 耳鼻臨床 $90: 361 \sim 375,1997$.

35）飯野ゆき子，宮澤哲夫，石塚洋一：小児慢性副鼻腔炎に対 するマクロライド療法の有効性. 耳展 40 補 $2: 159 \sim 163$, 1997.

36）室野重之, 古川 仞：小児副鼻腔炎のクラリスロマイシン 療法. 耳鼻臨床 $91: 863 \sim 866,1998$.

37）小川真滋, 藤田和寿 : 小児慢性副鼻腔炎に対するクラリス ロマイシン・カルボシステイン併用療法の検討. 耳鼻 43 : 804 808, 1997.

38）柳清 : 慢性副鼻腔炎に対する使用法のコッ一術後の マクロライド使用一. JOHNS $12: 229 \sim 234,1996$.

39）松根彰志, 江川雅彦, 上野員義, 他 : ロキシスロマイシン 投与持よびレーザー鼻内手術後 YAMIK カテーテル法に より改善した副鼻腔気管支炎症例. 耳鼻 41: 913 918, 1995.
40）田中久夫：14員環マクロライド十テオフィリン十抗アレル ギー剂療法の治療効果とテオフィリン血中濃度による相互 作用評価括よび添付文書での検討. 日耳鼻感染誌 15:14 $\sim 19,1997$.

41）馬場駿吉, 大山 勝, 新川 敦, 他 : マクロライド療法の 安全性を考光る。耳展 $41:$ 404 410, 1998.

42) 北田光一: 薬物代謝学の勘どころ一薬物相互作用のカギ を握る P450一。. 月刊薬事 38 : 467, 1996.

43）三笠桂一, 澤木政好, 古西 満, 他 : 慢性下気道感染症に 対する Erythromycin 長期化学療法の検討 第 3 報 一投 与期間 3 年以上の症例を中心に一. 感染症雑誌 $66: 561 \sim$ $567,1992$.

44）田中久夫：慢性副鼻腔炎に対するマクロライド系抗生剂低 用量長期投与症例の比較検討. 日耳鼻感染誌 $15: 13 \sim 17$, 1997.

別刷請求先 : 大山 勝 干894-0046 鹿児島県名瀬市小宿3411 社団法人大島郡医師会病院 